\title{
Social Capital as a Local Wisdom of Farmer in Managing Agricultural Resources in Lubuk Pakam Sub-district, Deli Serdang District
}

\author{
Sihar Pandapotan ${ }^{1}$, H. Silalahi ${ }^{2}$ \\ ${ }^{1}$ Terbuka University of Medan, Indonesia \\ sihar@ecampus.ut.ac.id
}

\begin{abstract}
This study will relate to the concept of sustainable development where the emphasis is not only on economic growth alone, but on socio-cultural factors that lead to the wise use of the environment. This research traces various forms of local wisdom as social capital for paddy rice farmers in Deli Serdang District. Besides as a form of preserving the environment wisely. But also as one of the solutions in solving human and environmental problems. This study uses a qualitative research method with a descriptive approach. This method and approach was chosen because in carrying out the documentation it is necessary to have a holistic description of a study. The results showed that paddy rice farmers in Deli Serdang District had combined forms of local wisdom with technological advancements as social capital in managing agricultural resources. This is shown in the process of farming that still uses traditional methods but is also supported by modern farming tools. In general, the form of local wisdom is demonstrated through the revitalization of mutual cooperation values, growing the collectivity of farmers, and the implementation of simple rituals as a form of gratitude. Therefore, the preservation of various forms of local wisdom with a global perspective is one of the social capital and references in improving the quality of farmer's life in particular, and the development of Indonesian agriculture in general.
\end{abstract}

Keywords: Local wisdom; agriculture.

\section{Introduction}

Farmers, because of their profession and dependence on agriculture, become experts and professionals in their fields. Farmers with local wisdom as their social capital are able to manage sustainable agricultural resources. The role of government bureaucracy and nongovernmental organizations is to facilitate the improvement of the quality of farmers' human resources and social capital. However, the rice intensification policy implemented by the government so far has weakened social capital and the independence of these farmers. Farmers become passive and merely implement government programs (Surono, 2011).

Various local wisdoms that have been maintained by ethnic groups in Indonesia are learned from nature, and consider everything that is good and useful, which they also learn from nature. Of course, the activities carried out continuously and passed on to the next generation are believed by anthropologists as an effort to preserve culture. The experts have poured many ideas related to development which are expected to achieve the balance of nature and human needs. Various environmental ethics have become studies that are often voiced in efforts to preserve environmental ecology. Local wisdom (Tirsa, 2012) becomes a potential energy and strength that can guide the community to develop a set of activities that meet the needs of life that still responds to the conditions of the natural environment. As revealed by Arkanuddin (2001) that local values and knowledge are embedded in people's way of life as a means to survive. Acting locally in anthropological terms is often juxtaposed with activities to understand and preserve local wisdom (Nurjannah, et al, 2019). 
The local wisdom of farmers in Deli Serdang District in managing the agricultural system is a knowledge that arises in the local community in addressing and considering all the good, bad and useful for life activities that are specific to the management of their agricultural land. Local wisdom that is considered to provide benefits in agricultural products, then made an implied order to be implemented so that agricultural products remain consistent and do not experience crop failure.

Local wisdom acts as a space of interaction that has been designed in such a way that involves a pattern between humans and humans, as well as humans and nature. The pattern that has been designed is called a setting. A setting that is formed will produce values. Then these values become the basis of their relationship or become a reference for behavior (Ridwan, 2007).

\section{Research Methods}

The research method that will be used is descriptive qualitative. Descriptive qualitative method is an effort that can clearly describe the data needed in a descriptive study. According to Bogdan and Taylor defining qualitative methods is a research procedure that produces descriptive data in the form of written or oral words from people and observable behavior.

The research location is Lubuk Pakam Sub-District, Deli Serdang District. The informants are farmers, farm laborers, middlemen/tauke, and village or Sub-district officials. The technique of selecting informants or research subjects is based on the criteria put forward by Spradley namely: simple, there is only one single social situation, easy to enter it, and no effort in conducting research, easy to obtain permission, its activities occur repeatedly.

Data collection in this qualitative study uses several data collection techniques. In this study, data collection techniques were used with (a) observation (b) in-depth interviews and (c) documentation. The data analysis technique used in this study is the analysis of qualitative model data such as Miles and Huberman (in Iskandar, 2009: 139) which consists of three activities, namely data reduction, data presentation, and drawing conclusions.

\section{Discussion}

The majority of people in Lubuk Pakam Sub-District, Deli Serdang District have jobs as farmers. This is due to the area around this district is an agricultural area with a vast expanse of paddy fields so that people prefer to work as a farmer. The majority of people who live in this district are Javanese. However, there are also other ethnic groups as farmers in this area, who are ethnic Toba, Karo, Simalungun, Malay and others. One of the village is Sikepel Village, farming communities are not all permanent residents, but many come from the surrounding villages. This is because agricultural land in this area is already widely owned by people who are outside the area so that most farmers rent agricultural land or only work on other people's agricultural land. There are two ways to pay land rent in this area, namely by paying for the land area and also paying land rent at the price of paddy per grain at the time of harvest. This depends on the agreement between the owner and tenant of the land which is usually always paid every post-harvest by the tenant of the land.

The agricultural process in this region has used a lot of advances in technology, especially in the equipment used by farmers to support agricultural activities. However, in the 
process the process is also inseparable from the traditional methods that are still maintained and used by farmers to this day. The community certainly still uses traditional methods that are supported by advances in existing technology. This is because farmers cannot close their eyes that current technological advancements do indeed bring abundant yields to their agriculture. In addition, there are various counseling given by the agriculture service to the farmer groups in providing direction to farmers to further increase agricultural production by using more modern tools. There is also assistance from the relevant agriculture service in providing agricultural equipment such as jetors (tractors), water pumping machines, chemical fertilizers and others. So that over time people are more likely to use more modern tools and use chemical fertilizers to support their agricultural processes in obtaining more abundant agricultural products.

Significant increase in farmers' yields is inseparable from a number of simple systems and policies which later became local wisdom including;

\subsection{Revitalizing the Value of Mutual Cooperation}

Revitalization of the value of mutual cooperation is no longer located in the instrument of management in a field of rice fields together, but by fostering a sense of togetherness among farmers to move to manage their respective farms collectively. The system of managing rice fields simultaneously or together which is re-applied by farmers is the result of mutual consultation with farmers and local government. This then becomes an idea that is mutually agreed upon to be implemented.

The existence of a policy of the results of deliberations with farmers to carry out the agricultural system simultaneously starting from the beginning of the management of paddy fields for planting to the maintenance and harvest of agricultural products. The paddy field management collectivity is carried out simultaneously although each farmer's paddy field helps solve some farmers' problems such as animal pest disturbance. Bird pests are known as a nuisance that often consumes the developing grains of paddy, so that not infrequently when the harvest comes, the grains of rice are left little and cause a decrease in the quantity of the crop. Unfirming the time simultaneously in starting to plant, will make the development of paddy grow simultaneously in all fields. Creating a network that is interconnected to all areas of paddy fields owned by other farmers and making 'scarecrow' help in the removal of bird pests. Control of rice fields will be carried out simultaneously also by farmers. The existence of a strategy of planting together without realizing it also provides other benefits, namely raising awareness among fellow farmers. Slowly eliminating the egocentric attitude that only focuses on the fields themselves.

Nature sometimes creates different conditions in the development of paddy in the paddy fields of farmers even though planting is carried out simultaneously. The condition of one of the farmers 'fields enters a faster stage than the neighboring farmers' fields. The farmer's paddy field is already in the stage of draining water in the paddy field, while the farmer's paddy field next to it is still around a few more days to arrive at that stage. However, the farmer waited a few days later for drying. This is due to weigh the adverse effects that will impact on the development of paddy in other farmers' fields next to their fields that have not yet entered the drying stage of paddy fields.

In addition, the same thing also sometimes happens in the irrigation system. Some farmers experienced internal problems in completing paddy plowing. Other farmers will wait for farmers who have not yet completed the plowing of the rice fields to complete the loose 
soil in their fields. Only then will the farmers plant paddy simultaneously and irrigate the paddy fields simultaneously by asking for help from the local government in charge of maintaining the irrigation system. The existence of a strategy of planting simultaneously also includes irrigation of paddy fields which is also simultaneously. It also maintains the quantity of water that is evenly obtained by all farmers' fields.

\subsection{Growing the Collectivity of Farmers}

The results of deliberations between farmers and the local government resulted in a renewal of the system, ways of thinking and acting. Management of individual paddy fields and ignoring the situation in other farmers' fields is recommended to be abandoned. Based on the results of interviews with Informant, it was explained that since 2007-2009, the order that they agreed to be implemented as a whole turned out to produce results with increased yields. The collectivity of farmers who grow slowly led to an attitude of mutual care with other farmers and cooperate with each other. This then becomes a farmer's social capital that minimizes conflicts between farmers.

Maintaining harmony together in the processing of paddy fields gives the power to the farmers to control, supervise, irrigation and other things together. Farmers can also discuss and exchange ideas on issues of agriculture because good emotional closeness has been developed. Intense interactions between farmers unknowingly lead to a sense of concern and the loss of prejudice that often triggers conflicts between farmers.

\section{Simple Rituals as an Expression of Gratitude}

Like farmers in other regions, farmers in Deli Serdang still practice traditional practices or rituals related to the agricultural system. However, this ritual also does not become a force for farmers to carry out. Customs and rituals for some farmers have been considered as a form of gratitude to God Almighty for continuing to assist them in managing agriculture. The essence of customs or rituals often done by the previous ancestors in managing agriculture has also undergone a change. Even the traditional practices or rituals are simpler and there is no coercion to do. Moreover, the majority of farmers are followers of Islam. However, there are still some farmers who believe in the success of their harvest related to offerings given to Dewi Sri.

Even though the ritual offering is not as perfect as the usual order, there are still many farmers who do it in a simple form, such as collecting some paddy seeds which are then bound and placed in the fields while conveying requests and prayers so that the fields do not experience a bad process.

According to the belief of the Javanese people, Dewi Sri is a Goddess who can take care of the paddy planted so that the harvest fails. Farmers now offer simple offerings, it's just that according to the informant's explanation that this is not identified with Dewi Sri's willingness to protect the paddy fields to provide good harvests. At present the farmers are more convinced that if a farmer experiences a crop failure when other farmers experience a successful harvest, all are associated with the many bad behaviors that the farmer does when planting to harvest. The ugliness of this behavior is considered to make the creator give a warning to him through not maximizing the yield of the crop. However, other farmers often reminded farmers who experienced crop failures with a joke "Dewi Sri is angry".

Harvest failure in farmers is not only a logical understanding related to natural factors, unless the farmers experience the harvest failure simultaneously. However, many farmers 
consider that the results of rice fields are related to the elements in humans, namely the farmers. Harvest failure is often interpreted as an afterthought that there are still many bad behaviors carried out by farmers, thus impacting on yields. Therefore, farmers always remind each other to maintain daily behavior so as not to overdo it and become a bad thing.

Stages of the Process of Management of Agricultural Resources:

1. Land Management Stage

In the agricultural process in this region through several stages in the process of managing agricultural resources. The first stage carried out by farmers in starting the agricultural process is the management of land called $\mathrm{Ngluku}$ as the process of plowing the rice fields. This is certainly influenced by factors of people who live in this village are Javanese ethnicity so that other ethnic groups also use and recognize the term ngluku as the process of plowing paddy fields. The term Ngluku in Javanese is interpreted as a tool made from a long piece of wood to flatten plowed soil and an iron plow to cut dry stalks of rice that has dried and loosened the soil or better known as the process of plowing the paddy after harvest.

In this area, they have used tools which are often called jetors (tractors) in plowing rice fields and have long no longer used animal power to plow fields, this is because people feel that using tools in the form of jetors (tractors) feels more effective and efficient in terms of time and costs incurred by farmers. The Ngeluku process (plowing the fields) is usually carried out by 1-2 people in turn. Usually in one day the process of ngluku done by jetor only takes 1 day to. This efficiency is of course felt to be very meaningful for farmers in maximizing the time of land management. Wages for plowing rice fields with tools are calculated at Rp. 60,000 per 400 meters.

\section{Nursery Stage}

At the nursery stage of the paddy seedlingsquality must be really considered because good paddy seeds greatly affect the yield of harvest later. In general, farmers in this area can buy paddy seeds in farmer groups, fertilizer stalls or paddy storage during the previous planting period. In the nursery process, farmers still use traditional methods that are still used today and cannot be replaced by advances in existing technology. The selected paddyseedlings are then soaked in water for 2 days 2 nights. This has always been always done by farmers because farmers believe that soaking paddyseeds in the first place can stimulate the growth of seedling root sprouts so that it make it easier to grow seedlings when seeding later.

Furthermore, farmers make "bedeng", which means that the place to grow rice is done by raising the soil and usually in the form of boxes. Making these beds serves as a place to seed rice seedbed later. For the size of the beds themselves, farmers usually make / count them manually according to the many rice seeds to be sown and the area of agricultural land owned by farmers and also the position of the beds is usually on the edge of rice fields. This is done so that the rice seeds that are ready to be pulled later will be easier to transfer to agricultural land and the time needed is also shorter. The way to make beds is still very traditional by using simple tools such as hoes to elevate the soil, long wood (bamboo) to level the existing pile of soil, and long ropes as a tool to measure width and measure the distance between one bed and another. 


\section{Seeding Stage}

After the seeds are soaked, the seeds are sown carefully and evenly so that later the growing paddy seeds do not overlap. Paddyseeds that have been sown must also not be submerged in too much water or too dry, because according to farmers' understanding if too much paddyseed is inundated and too dry it can cause paddyseeds to rot and their growth fails, this process is referred to as the nursery process carried out during \pm 17 days and one week after the nursery farmers usually give fertilizer to the rice seedlings so that the seeds are quickly stimulated and so that they can grow well so that the planting of paddy will be done sooner.

\section{Planting Stage}

After seeding for \pm 17 days, at this time the paddy seeds were already about $15-25 \mathrm{~cm}$ high and the time for the rice seeds to be moved to a wider paddy field. In this area paddyseedlings are usually pulled out in the traditional way by cutting the roots of the seedlings with a simple tool, which is a sickle (a tool made of iron and in the shape of an arch used for cutting). The seeds that have been pulled out are then transferred by pulling them and spreading them on the paddy field. Before planting the paddy, farmers usually give fertilizer first to avoid the snail pests that are often found in the fields. This must be done first because at the age of young seedlings like this is very easy for the snails to damage and eat the leaves of the seeds and of course make paddygrowth not optimal later.

The process of planting paddyin this area is still done manually by the community that is the traditional way that usually farmers only use long ropes as a tool and benchmarks in estimating the distance between paddyseeds. The process of planting paddyin this area is still the same as before, using traditional methods. The difference lies in the process that has used the wage system and is no longer done as before, namely alternately between paddy land owners and carried out voluntarily which is used as a habit of the community in tightening the kinship and building a sense of togetherness among fellow citizens.

After the planting process is completed, the farmers must also provide fertilizer and pesticides on a regular basis which can function as an incentive so that the paddysoon grows bigger and produces good rice fruit and also as a prevention of pests and diseases that can damage paddyplants. Provision of fertilizers and pesticides must be done according to schedule and also the right dose because if given too much can also damage paddyplants. Fertilizers and pesticides used by farmers in this area are also generally made from chemicals, namely Urea, KCL, ZA, SP36 and others.

In addition to paying attention to the provision of fertilizers and pesticides, a lot of water in the paddy fields must also continue to be considered and adjusted to the needs of paddythat has been planted. Every paddy field has irrigation which functions as a storage for water supply and is a place that is very helpful for farmers when they need water for their agricultural land. How to drain water can also be done in traditional and modern ways. The traditional way is to drain water manually which can be flowed through other farmers' fields first. Usually this method is very beneficial for farmers who have agricultural land close to irrigation because farmers do not need to pay additional costs. However, this method also sometimes makes farmers often disagree and of course it requires a long time in the process of water drainage. The modern way is to drain water with the help of a water pump engine. This method is quite helpful in reducing the discrepancy between farmers and the fast 
flowing water, but when using machinery, farmers must incur additional costs such as buying water pumping machines, gasoline and water hose to drain water to their paddyfields.

\section{Harvesting Stage}

At this stage there are usually a lot of pests of birds and rats so that farmers are often found using a simple method of making around the scarecrow paddy fields and also cans of used milk which are filled by small stones so that when the wind blows hard or shaken it will issue sounds to scare away pests of birds and rats which if left unchecked can be detrimental to farmers. Until now this method is still a fairly helpful way and continues to be done every time before the harvest in repelling bird and mouse pests. Because in the pre-harvest, farmers usually no longer provide fertilizer or pesticides to their farms. In addition, rice that is ready to harvest is marked by the color of paddyand its leaves are already brownish yellow. Paddyhas been seen to be filled and increasingly ducked and usually by that time the rice is around \pm 110 days old.

Furthermore, the paddyis ready to be harvested. There are two machines used in paddyharvesting in this area, namely with the Theresher engine and with the Quick Tractor engine. Theresher machine is a machine that can separate between stems and paddyseeds. However, this machine still requires a lot of additional workers who have to manually mite the rice and collect it to be separated between the stems and seeds of paddyand of course requires a long time. While the Quick Tractor engine is usually known as 'odong-odong'. This machine also has the same function as the Theresher engine, but in its use it is very simple and does not require a long time. Because this machine can run in the fields with only need 34 people which one person as the driver and 3 more people who accommodate the rice that has been separated from the stem.

After harvesting is usually to start the agricultural process again, the farmers have to wait for time for \pm 3 months. This is done so that the soil in the agricultural land can rest first and the nutrients present in the land can return. The process of restarting agriculture is also greatly influenced by the dry season because the prolonged dry season also makes it very difficult for farmers to obtain water that is very much needed in the process of agricultural activities. During the dry season, there are usually many farmers who fill their free time by planting plants that do not require much water and do not require difficult maintenance. Farmers in this area often grow corn, green beans, long beans and watermelons, which are easy to maintain and do not require expensive costs.

\section{Conclusion}

The agricultural process in Deli SerdangDistrict at this time indeed has a lot to use advances from existing technology. However, in some farming processes, farmers still continue to use traditional methods that have been hereditary since ancient times. Technological advances are inevitable in everyday life, including in agriculture. However, local wisdom that has existed for a long time is still preserved because not always technological advances can always be better in helping and facilitating all existing work processes. However, there are some jobs that are better if done in traditional ways. Therefore, between technological advances and local knowledge, it should be done in the same manner in order to facilitate the existing work but still not leave the processes that have been around for a long time. 


\section{References}

Arkanuddin, Sistem Perladangan dan Kearifan Lokal Orang Dayak dalam Mengelola Sumber Daya Hutan. Bandung, 2001.

D. Indro Surono, Hutang pada Petani Padi. Jakarta: KRKP, 2011.

Iskandar, Metodologi Penelitian Kualitatif. Jakarta: Gaung Persada, 2009.

L. J. Moleong, Metode Penelitian Kualitatif. Bandung: Rosda, 2007.

Nurjannah, T. Simarmata, Supsiloani, T. Andayani, A. Febryani, and B. K. Amal, "The Implementation of Local Wisdom Education Global Insights in Institutional and Local Wisdom of Culture in North Sumatera Subject in Faculty of Social Science , Universitas Negeri Medan," vol. 208, no. Icssis 2018, pp. 138-143, 2019.

N. Ridwan, "Landasan Keilmuan Kearifan Lokal," J. Stud. Islam dan Budaya Ibda', vol. 5, no. 1, pp. 27-38, 2007.

O. Tirsa, "Praktik-Praktik Kearifan Lokal dalam Pengelolaan Sumber Daya Pertanian Padi Sawah,” Institut Pertanian Bogor, 2012. 